\author{
Фабрика-Процька Ольга Романівна, \\ кандидат мистецтвознавства, \\ доцент кафедри музичної україністики \\ та народно-інструментального мистецтва \\ Навчально-наукового Інституту мистецтв \\ ДВНЗ «Прикарпатський національний \\ університет імені Василя Стефаника» \\ olgafp4@ukr.net \\ ORCID 0000-0001-5188-1491
}

\title{
ДИНАМІКА КУЛЬТУРНОЇ ТА ЕТНІЧНОЇ ІДЕНТИФІКАЦЇ̈ НА УКРАЇНСЬКОМУ ПОГРАНИЧЧІ В ПЕРІОД СЬОГОДЕННЯ
}

Мета дослідження - розкрити динаміку функціонування культурної та етнічної ідентифікації на українському пограниччі в сучасний період. Методологія дослідження полягає у використанні теоретичного, історичного, культурологічного, мистецтвознавчого підходів, що дало змогу розкрити взаємодію тенденцій, репрезентованих явищами полікультурності, а також взаємозв'язок між етносами, регіонами та країнами в наш час. Наукова новизна. У статті вперше комплексно акцентовано увагу на динаміці розвитку культурної та етнічної ідентифікації на українських пограничних територіях. Висновки. Зазначено, що на українських пограничних територіях в наш час відбуваються соціальні зміни, а саме: відкриваються нові можливості для їх мешканців, розвивається співпраця у соціальній, економічній та культурній сферах та ін. Доведено, що теоретичне обгрунтування питання культурної та етнічної ідентифікації сприяє розвитку національного зацікавлення, усвідомлення якого є необхідною складовою розвитку українського суспільства.

Ключові слова: етнос, пограничні території, трансформація, культурна та етнічна ідентифікація, регіональність.

Фабрика-Процкая Ольга Романовна, кандидат искусствоведения, доцент кафедры музыкальной украинистики и народно-инструментального искусства Учебно-научного института искусств ДВНЗ «Прикарпатский национальный университет имени Василия Стефаника» современный период

Динамика культурной и этнической идентификации на украинском пограничье в

Цель работы - раскрыть динамику функционирования культурной и этнической идентификации на украинском пограничье. Методология исследования заключается в использовании теоретического, исторического, культурологического, искусствоведческого подходов, что позволило раскрыть взаимодействие тенденций, представленных явлениями поликультурности, а также взаимосвязь между этносами, регионами и странами в наше время. Научная новизна. В статье впервые комплексно акцентировано внимание на динамике развития культурной и этнической идентификации на украинских пограничных территориях. Выводы. Отмечено, что на пограничных территориях в наше время происходят социальные изменения, а именно открываются новые возможности для их жителей, развивается сотрудничество в социальной, экономической и культурной сферах и др. Доказано, что теоретическое обоснование вопроса культурной и этнической идентификации способствует развитию национального интереса, осознание которого является необходимой составляющей развития украинского общества.

Ключевые слова: этнос, пограничные территории, трансформация, культурная и этничная идентификация, региональность.

Fabyka-Protska Olga, Candidate of the Art critic, docent the Department of Musical Ukrainian Studies and Folk Instrumental Music Art Institute of Art of the Precarpathian National University after Vasil Stefanyk

Dynamics of cultural and ethnic identification at the Ukrainian borderland within the modern period

The purpose of the article is to reveal the dynamics of the functioning of cultural and ethnic identification on the Ukrainian border in the modern period. The methodology of the study is to use theoretical, historical, cultural, artistic, and scientific approaches, which allowed us to reveal the interaction of trends represented by the phenomena of multiculturalism, as well as the relationship between ethnicities, regions, and countries in our time. Scientific novelty. For the first time, the article focuses on the dynamics of the development of cultural and ethnic identification in the Ukrainian border territories. Conclusions. It is noted that social changes are taking place in the Ukrainian border

(C) Фабрика-Процька О. Р., 2019 
territories, namely, opening new opportunities for their residents, developing cooperation in the social, economic, and cultural spheres, etc. It is proved that the theoretical substantiation of the issue of cultural and ethnic identification contributes to the development of national interest, awareness of which is a necessary component of the development of Ukrainian society. Identity and identification processes in similar areas occur on a symbolic level. According to K. Shestakova, in our time, transboundary regions are formed with their own identity, in which local or regional identification dominates over others. At the same time, in ethnically mixed territories (the factor of interethnic contacts is extremely strong here, almost the main one), the set of several identities in which the ethnic aspect is most pronounced is traced. Thus, the relationship between global and national factors of the contemporary historical process in Ukraine is diverse, complex, and contradictory. They can contribute to the development of integration of a country into the world community or slow down this process. The interaction between the specificity of ethnic and cultural identity on the Ukrainian border is a pressing issue today.

Key words: ethnicity, border territories, transformation, cultural and ethnic identification, regionality.

Актуальність теми дослідження. Серед особливостей сучасного розвитку країн Свропи відчувається посилення ролі етнічного фактору у культурних, суспільно-політичних процесах, а також бажання людей відстояти свої національні й культурні традиції та цінності. Елемент етнічності набуває чималого значення, оскільки безпосередньо впливає на функціонування культурних, соціальних процесів та розподіл суспільних ресурсів. Глобалізаційні процеси надзвичайно актуалізували проблему національно-культурної ідентичності, яка сьогодні перетворилася на одну 3 найважливіших проблем серед науковців не лише в Україні, а й за ії межами.

Питання культурної та етнічної ідентифікації є досить актуальним у наукових колах України та інших країн. Це обумовлено, з одного боку, тим, що визначення української ідентичності є певним теоретичним засобом створення національної держави. 3 іншого боку, теоретичне обгрунтування цієї проблеми сприяє висвітленню національного зацікавлення, усвідомлення якого є необхідною складовою розвитку українського суспільства.

Трансформаційні процеси, що розвиваються в сучасній Україні, приводять до змін у становищі всіх соціальних груп. Це сприяє формуванню нових соціальних та міжкультурних зв’язків. За визначенням окремих дослідників, своєрідність етносоціальної ситуації в Україні визначають такі риси, як етнополітичний ренесанс національних меншин та присутність в окремих регіонах компактних та численних етнічних груп. Соціальні зміни відбуваються на пограничних територіях. Зокрема, збільшуються можливості для мешканців пограниччя, значно зростає інтенсивність між групових контактів, розвивається співпраця у економічній, соціальній та культурній сферах, посилюється фактор міжетнічної взаємодії.

Слід констатувати, що «...сучасний культурний розвиток характеризується взаємодією тенденцій, репрезентованих явищами полікультурності, інтеграцією між країнами, регіонами, етносами, націями, які формують спільні інститути діяльності, що надають більше можливостей для розвитку цивілізації» $[9,98]$.

В період сьогодення саме для мешканців пограничних територій усвідомлення групової та індивідуальної ідентичності стало надзвичайно актуальним. Це пояснюється передусім невизначеністю соціальних шляхів розвитку пограничних регіонів. «Внаслідок зростання соціальної мобільності через близькість кордону збільшилася спокуса «запозичити» модель сусіднього, чужого суспільства, й оминути таким чином вироблення власних координат для соціального самовизначення» $[12,3]$.

За висловом М. Козловець, якщо для західних науковців концентрація їхного наукового зацікавлення довкола етнічного, національного та етнополітичного різновидів ідентичності зумовлена насамперед глобалізацією з їі руйнівними наслідками для національних держав і етнічних культур, то в нас - триваючими процесами націє - та державотворення [5].

Аналіз досліджень і публікацій. Різні аспекти зазначеної тематики знайшли свої відображення в працях таких вітчизняних дослідників, як Є. Андрос, А. Астаф’єв, Ю. Бадзьо, І.Бойченко,С. Веселовський, А. Гальчинський та ін.

Про специфіку та пояснення суспільних процесів у пограничних регіонах польськими дослідниками - Г. Бабінським, Д. Вояковським, А. Садовським та А. Клосковською була впроваджена концепція пограниччя, використання якої дає можливість обгрунтувати соціальні зміни на науково-практичному й теоретичному рівнях. Однак мало уваги приділено для розуміння етнічних ідентифікаційних процесів у наш час.

Темі аналізу місця, ролі та значення етнічного фактора в життєдіяльності сучасного суспільства присвячені роботи 3. Маха, Ф. Барта, Л. Л. Ворнера, Е. Гіденса, Х. Віккера, С. Макеєва, М. Шульги, О. Гнатенка, В. Павленка, В. Арбеніної, 3. Сікевич, В. Хотинець та ін. 
Відомими є праці, що розкривають поняття та явища «кресів» - специфічних історикокультурних регіонів Польщі, а також звертають увагу на формування в суспільній свідомості уявлення про своєрідну економічну, політично-культурну та соціальну атмосферу східних погранич Польщі, а також прозорість кордону між Україною та Польщею.

Різноманітні аспекти політичного, суспільно-культурного розвитку пограничних територій теоретично обгрунтовано Г. Бабінським, І. Буковською-Флоренською, Є. Єсталь, М. Голка, В Павлючок; етнічну та національну ідентичність висвітлюють праці 3. Ясинського, А. Садовського, Д. Вояковського та ін. Питання перспектив розвитку програничних теренів у процесі європейської інтеграції розкривають дослідження П. Кубицького, Г. Пожарлік тощо.

Аналіз взаємодії регіональної ідентичності та етнічної взаємодії розкриває у своїх працях дослідник I. Кононов. Загалом розгляд етнічних процесів присутній у сфері міждисциплінарних етнічних досліджень (Л. Полякова, О. Болдецька, І. Кононов, О. Стегній, М. Чурилов, К. Коростеліна, В. Павленко, В. Свтух та ін.), які спрямовані на переосмислення модерністських та класичних підходів до етнічності.

Синергетику регіональних ідентичностей у культурному континуумі України кінця XXпочатку XXI століття розкриває наукове дослідження О. Яковлева, який слушно зазначає, що «Саме синергетичне мислення, що розвиває методологію системних досліджень, відкриває нові можливості пізнання закономірностей саморозвитку та самоорганізації сучасного українського суспільства, яке переживає свою соціокультурну трансформацію в незалежну державу в умовах світових процесів глобалізації та альтернативного поглиблення етнонаціональних регіональних ідентифікацій» $[13,5]$.

Специфіку пограничних територій досліджували польські науковці Г. Бабінський, Д. Вояковський, А. Садовський, А. Клосковська та інші.

У процесі вивчення та аналізу «кресів» - специфічних історико-культурних регіонів Польщі, митці звертали увагу на формування в суспільній свідомості уявлення про своєрідну політичнокультурну, економічну та соціальну атмосферу східних погранич Польщі, прозорість кордону між Польщею та Україною в усіх значеннях. Відомими є публікації та монографії Р. Кєрновського, 3. Кужової, А. Лятали та багатьох інших.

Мета дослідження - розкрити динаміку функціонування культурної та етнічної ідентифікації на українському пограниччі в період сьогодення.

Виклад основного матеріалу. Ідентифікація та свідомість створюються на базі певних об'єктивних рис, хоча можуть бути незалежними від них. Будучи Етнічна ідентифікація, як одна 3 форм соціальної ідентифікації, окреслюється в категоріях культурної єдності й спирається, за визначенням К. Шестакової, на самодефінацію, створену на підставі культурних характеристик указаної групи в опозиції до інших груп [11].

Етнічна самоідентифікація в ідентифікаційних практиках часто зіставляється 3 поширеним поняттям «етнічна самосвідомість». Наприклад, Є.Александренков стверджує, що почуття приналежності до групи, сформоване англомовними вченими як ethnic identity, мало чим відрізняється від розуміння «етнічної самосвідомості». Відмінність полягає лише в розумінні термінів «етнічна група» й «етнос» $[1,13-22]$.

Вдало підкреслює дослідник О. Болдецька, що етнічна ідентифікація - це самовизначення індивідом своєї етнічної належності, до якої входить сукупність уявлень як про етнооб'єднувальні, так і про етнодиференціювальні ознаки... Етнічна самоідентифікація, на іiі думку, відбувається як процес ототожнення суб'єкта зі своїм етносом. В основі цього процесу лежить принцип зіставлення «ми-вони» $[2,20]$.

У 1966-1967 pp. Ю.Бромлей дає чітке визначення поняття «етнос», яке надовго закріпилося в радянських суспільних науках: «Етнос - усталена сукупність людей, яка історично склалася на певній території та має спільні, відносно стабільні особливості мови, культури й психіки, а також усвідомлення своєї єдності та відмінності від інших подібних утворень (самосвідомість), зафіксоване у самоназві (етнонімі)» $[8,54]$.

Серед науковців існує два окреслення терміна «етнічність». У вузькому розумінні, за визначенням Г.Де Вос та Л.Романучі-Росс, термін «етнічність» збігається 3 поняттям «етнічна ідентичність», що означає почуття безперервності 3 минулим i $\epsilon$ частиною автодефініції на найглибшому психологічному рівні. У зв'язку з цим, як вказує 3. Мах, в категоріях культурної єдності етнічність стає однією 3 форм суспільної ідентичності та спирається на визначення, які створюються на підставі культурних характеристик цієї групи стосовно інших груп. I, як ефект класифікації та упорядкування суспільного світу, належить передусім до почуття приналежності та самооцінки [16]. 
Польський дослідник Г.Бабінський, полемізуючи над етнонаціональними процесами останнього десятиліття, слушно зазначає, що термін «етнічність» найбільше підходить для означення своєрідного суспільного зв'язку та умов існування суспільних груп [14]. Це пояснюється, насамперед, тим, що етнічність перестали розуміти як атрибут тільки меншинних угрупувань, емігрантів чи пограничних меншин. Він узагальнює поняття етнічність та наводить моделі використання, серед яких:

1) етнічність як етнічна група, набір рис певної спільноти - етнічної групи, якій притаманні різнорідні риси. Найчастіше - це спільні походження, культура, система цінностей. На його думку, члени цієї групи можуть мати означені риси або не знаючи про це, або не приділяючи цьому належної уваги, що, однак, не перешкоджає існуванню групи. Це концепція об'єктивної етнічності;

2) етнічність як етнічна ідентифікація - усвідомлення окремості, гордість або, навпаки, небажання (як в концепції самоненависті). Етнічна ідентифікація і свідомість створюються на базі певних об'єктивних рис, хоча й можуть бути незалежними від цих рис. «Етнічність може створюватись і розвиватись без об'єктивних підстав групової окремості, на базі виключно свідомості та ідеології» $[12,42]$.

Динаміку прикордоння, на думку В. Кочана, як соціокультурного феномену, слід розглядати в двох вимірах: зовнішньому та внутрішньому. Перше - це зміни ролі й значущості пограниччя в соціокультурних процесах. Друге - внутрішні соціокультурні трансформації того чи іншого пограниччя $[6,96]$.

У Закарпатській області, яка межує з Угорщиною, Польщею, Румунією, Словаччиною національний склад представлений українцями, угорцями, румунами, ромами.

Основні географічні межі українсько-польського пограниччя науковці Польщі Г. Бабінський та Д. Вояковський окреслюють такими населеними пунктами: Мостисько, Грудек, Львів, Самбір, Дрогобич, Золочів, Стрий, Івано-Франківськ, Коломия, Тернопіль, Підволочиськ з українського боку; любачівський, ярославський, перемишльський, сяноцький, бещадський та лешський повіти 3 польського боку[18, 130].

Дослідники Т. Мазур і Л. Шевчук у статті «Особливості розвитку Львівської області як складової українсько-польського прикордоння» зазначають, що з економічної точки зору польськоукраїнський регіон обмежується чотирма регіональними адміністративними одиницями: Львівською та Волинською областями з українського боку, а також Люблінським і Підкарпатським воєводством 3 польського боку [7].

Етнічна територія - це історико-культурне утворення, яке не завжди збігається з територією держави. Зокрема, етнічна територія українців Пряшівщини - це географічний простір їхньої діяльності й проживання, які відображають і етнічні особливості цієї території, а саме: пам'ятки матеріальної культури, побутової сфери тощо. Найзахідніші українські території поєднуються 3 горами Карпат. Зокрема, слід зазначити, що «...на сучасному етапі, враховуючи специфіку міжрегіонального та транскордонного українсько-словацького співробітництва України та Словаччини з питань культури та забезпечення прав національних меншин в кожній з національних частин, важливим $\epsilon$ активізація співробітництва, в першу чергу у прикордонних регіонах» $[10,142]$.

Повертаючись до культурного контексту пограниччя, можна навести думку М. Щепанського, який вдало відзначає, що досить часто (хоча й не завжди) регіони, які колись справді знаходились поблизу державного кордону, сьогодні набули рис культурного пограниччя, поступово перетворюючись на регіони культурного пограниччя. На його думку, пограничним територіям, які ідеально відповідають типології культурного, властива локалізація на периферії великих політикоадміністративних центрів, тобто незмінна "кресовість", яка іноді може означати політичну, господарчу та суспільну маргіналізацію. Такий регіон може бути периферійним як в географічному сенсі, так і господарському, а вирізняти його може велика культурна відмінність; усвідомлене суспільне відчуття відмінності від інших (ми і вони, свої та чужі, тутешні та нетутешні). Узагальнюючи, М.Щепанський, формулює слушну думку про можливе місце, яке посідає прикордоння у світовій системі, або регіони культурного пограниччя та пограниччя взагалі [17].

Погоджуємося $з$ думкою дослідника 3 Польщі М. Голки, що «... прикордонні території чітко знають як відмінності між собою, так і подібності, звикли до свого співіснування, навчають співжиттю й співіснуванню різних груп та вимагають постійного тренінгу у співпраці, примушують змінювати стандартні схеми та відкидати стереотипи» [15, 19-20].

Висновки. Таким чином, у суспільному житті кордони $є$ умовною лінією, яка виражає різницю, поділи та позиції сторін - особистостей, суспільних груп, культур, держав. Теоретично 
кордони утворюють певні моделі прикордоння, які взаємопов'язані між собою. О. Яковлев слушно констатує, що українська ідентичність повинна мати й загальноцивілізаційну ментальність, тобто їі співвідношення із сучасною інформаційною епохою, полікультурним розмаїттям світу.

Ідентичність та ідентифікаційні процеси на подібних теренах відбуваються на символічному рівні. За висловом К. Шестакової, в наш час формуються транскордонні регіони із власною ідентичністю, в якій локальна, або регіональна ідентифікація домінує над іншими. Водночас на етнічно змішаних територіях (фактор міжетнічних контактів тут надзвичайно сильний, майже головний) прослідковується сукупність декількох ідентичностей, в яких етнічний аспект виражений найсильніше. Отже, взаємовідносини між глобальними та національними факторами сучасного історичного процесу в Україні різноманітні, складні та суперечливі. Вони можуть сприяти розвитку інтеграції тієї чи іншої країни у світове співтовариство або гальмувати цей процес. Взаємодія між специфікою етнічної та культурної ідентифікації на українському пограниччі $\epsilon$ актуальним питанням сьогодення.

\section{Jimepamypa}

1. Александренков Э. Г. "Этническое самосознание" или "этническая идентичность"? Этнографическое обозрение. 1996. № 3. С.13-22.

2. Болдецька О. А. Етнічна самосвідомість в українсько-російському прикордонні: автореф. дис. канд. соц. наук: 22.00.01. Харківський Національний університет історія соціології. Харків, 1996. 24 с.

3. Вахніна Л. Пограниччя в контексті сучасних глобалізаційних процесів: питання ідентичності. Одеські етнографічні читання. Етнокультура порубіжжя: локальнотериторіальні особливості : збірка наукових пращь. Колектив авторів. Одеса : «Одеський національний універститет імені I. I. Мечникова», 2014. 419 с.

4. Винер Б. Этничность: в поисках парадигмы. Этнографическое обозрение. 1998. №4. С.3 -27.

5. Козловець М. А. Феномен національної ідентичності: виклики глобалізації: монографія. Житомир: Видво ЖДУ ім. І. Франка, 2009. 558 с.

6. Кочан В. М. Феномен пограниччя у соціокультурному вимірі: дис. канд. філософ. наук: 09.00.03. Таврійський національний університет ім. В. І. Вернадського, Сімферополь, 2008. 206 с.

7. Мазур Т. М., Шевчук Л. Т. Особливості розвитку Львівської області як складової українсько-польського прикордоння. Соціально-економічні дослідження в перехідний період. Проблеми європейської інтеграції $\mathrm{i}$ транскордонної співпраці. Вип.XXIX: В 2 Т. Під ред. М.І.Долішнього. Львів-Луцьк: Волинський державний університет, 2001. Т.1. $421 \mathrm{c.}$

8. Павленко В. М., Таглін С. О. Етнопсихологія: навч. посібник. Київ: Сфера, 1999. 408 с.

9. Фабрика-Процька О. Р. Специфіка регіонально-культурної ідентичності українсько-євопейського пограниччя в період сьогодення. Культурні та мистецькі студії XXI століття: науково-практичне партнерство: матеріали міжнародного симпозіуму, 6 червня, 2019 р. М-во культ. України; Нац. акад. кер. кадрів культ. і мистець. Київ: НАКККіМ, 2019. 376 с.

10. Фабрика-Процька О.Р. Джерелознавчі та соціокультурні аспекти дослідження музичного фольклору пограниччя. Музичне мистецтво XXI століття - історія, теорія, практика: збірник наукових праць інституту мистецтва Дрогобицького державного педагогічного університету імені Івана Франка [загальна редакція та упорядкування А. Душного]. Дрогобич - Кельце - Алмати-Баку: Посвіт, 2019. Вип. 5. 556 с.

11. Шестакова К. Ю. Етнічна ідентифікація на українському пограниччі: автореф. дис. канд. соц. наук, Київ, $2005.25 \mathrm{c}$.

12. Шестакова К. Етнічна ідентифікація на українському пограниччі. Дисертація на здобуття наукового ступеня кандидата соціологічних наук. Київ, 2005. 187 с.

13. Яковлев О. В. Синергетика регіональних ідентичностей у культурному континуумі України кінця XXпочатку XXI століття: дис. д-ра культурології: 26.00.01. НАКККіМ, Київ, 2016. 468 с.

14. Babiński G. Pogranicze polsko-ukraińskie. Etniczność - zróżnicowanie religijne - tożsamość. Kraków: Nomos, 1997. $279 \mathrm{~s}$.

15. Golka M. Pogranicza - Transgraniczność - transkulturowość. Transgraniczność w perspektywie socjologicznej. Kontynuacje / Pod red. L.Gołdyki. - Zielona Góra: Lubuskie Towarzystwo Naukowe, 1999. S.13-26.

16. Mach Z. Symbols, conflict and identity. Kraków: Wydawnictwo Uniwersytetu Jagiellońskiego, 1989. 245 s.

17. Szczepański M. Na peryferiach systemu światowego? Socjologiczna refleksja wokół miejsca pogranicza kulturowego w układzie globalnym. Pogranicza etniczne w Europie. Harmonia i konflikty. Pod red. K.Krzysztofka, A.Sadowskiego. Białystok: Wydawnictwo Uniwersytetu w Białymstoku, 2001. S. 35-49.

18. Wojakowski D. Polacy i Ukraińcy. Rzeczy o pluralizmie i tożsamości. Kraków: Nomos, 2002. 298 s.

\section{References}

1. Alexandrenkov E. (1996). Ethnic identity or ethnic identity? Ethnographic review [in Russian].

2. Baldetska O. (1996). Ethnic consciousness in the Ukrainian-Russian border: Candidate's thesis. Kharkiv [in Ukrainian].

3. Vakhnina L. (2014). Borders in the context of modern globalization processes: the issue of identity. Odessa Ethnographic Readings. Ethnoculture of the border region: local territorial features. Odessa [in Ukrainian]. 